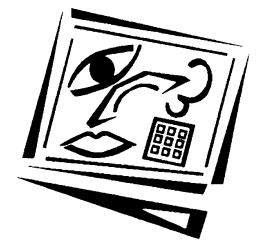

\title{
Assessing e-learning acceptance by university students in Thailand
}

\author{
Timothy Teo \\ University of Auckland \\ Wong Su Luan \\ Universiti Putra Malaysia \\ Thapanee Thammetar and Wisa Chattiwat
Silpakorn University
}

The aim of this study is to assess e-learning acceptance by students, using data collected from 377 students at three public universities in Thailand. Using the $E$ learning Acceptance Measure (Teo, 2010b), participants gave their responses to 21 statements on three factors hypothesised to measure e-learning: tutor quality, perceived usefulness, and facilitating conditions. Results showed that university students in Thailand have an above average level of e-learning acceptance (mean=111.36 out of 147). Among the user domains, age and perceived competence correlated significantly with the factors in ElAM. Using MIMIC modelling, students' elearning acceptance was found to be significantly different by age and perceived competence.

\section{Introduction}

In many educational systems, technology integration has been regarded among the top priorities in policy making, budget planning, and curriculum development. At the same time, technology is recognised as one of the key drivers for the improvement of teaching and learning (Afshari, Bakar, Wong, Samah \& Fooi, 2008; Wong, Atan \& Sabudin, 2010), prompting governments to launch major initiatives and make considerable capital investments to build and maintain information communication technology (ICT) infrastructures in the schools (Moses, Khambari \& Wong, 2008). In recent years, the Internet has not only fostered rapid access to information; it also facilitated changes in the nature of today's education (Wong, Ng, Nawawi \& Tang, 2005). By harnessing network technologies and wireless devices, teaching and learning is allowed to take place within and beyond the traditional classroom environment via electronic learning or e-learning. Many institutions, instructors, and policy makers have taken advantage of the flexibility of online learning in order to cater to the needs of current and potential students at all levels of education, including those who were unable to attend traditional courses on campus (Cheung, 2005; Dawson, 2006; Johnson, et al., 2011).

In many developing countries such as Thailand, students experience difficulties in their access to teachers and learning materials, and their exposures to learning resources are restricted to the locality where they are situated. In response to this 
situation, Thailand has focused most of its educational plans and policies on building ICT infrastructures and improving accessibility of ICT to teachers and students. According to the Southeast Asian Ministers of Education Organization (2010), these developments are important to reduce the rural-urban gap in education, by bridging the different level of access to ICT infrastructure, auguring well for the advancement of e-learning in the country (Southeast Asian Ministers of Education Organization, 2010).

Many higher institutions of learning around the world are aggressively offering online courses, taking advantage of the rapid development of the Internet technology (Yee, Wong, Mohamad Ayub \& Mahmud, 2009). To overcome constraints in teaching and learning, Thai universities have turned their attention to the use of e-learning by developing and delivering course materials through the Internet (Suanpang \& Petocz, 2006). Among other things, e-learning allows students in one place to learn from instructors in another place, thus overcoming the physical boundaries and in many instances, time constraints. Furthermore, e-learning has the potential to facilitate equity in higher education in Thailand. For example, students from low income families or who live far away from the city without the convenience of accessible transport can participate in e-learning to acquire knowledge and obtain training that is aligned with their aspirations and goals.

Some reported uses of e-learning in the Thai universities are the SIT e-learning system at the King Mongkut's University of Technology Tonburi (KMUTT) and the Thailand Cyber University project initiated by the Thailand Office of the Higher Education Commission. In both these institutions, e-learning is used extensively to support traditional face to face learning and to offer fully online courses for self development and those leading to formal qualifications e.g., Bachelor degrees.

With the proliferating use of the Internet for learning, users' reactions towards elearning are expected to vary according to their interactions with Internet-related activities, their behaviour, and their experience. However, despite the importance of elearning, few studies have been conducted on e-learning within the Thai context (Bhatiasevi, 2011). Among these, Suanpang and Petocz (2006), Siritongthaworn, Krairit, Dimmitt and Paul (2006), Saekow and Samson (2011) and Bhatiasevi (2011) opined that little is known about the e-learning situation in Thailand and this necessitates further explorations of the factors that affect e-learning acceptance among potential and current students, given the high stakes put in by the Thai government to promote this mode of learning, through large investments in ICT infrastructure and teacher professional development. In the context of this study, e-learning is referred to as distance learning where students learn through the Internet; and without face to face contact with their teachers, who are usually operating in a different location.

Acceptance of a technology such as e-learning refers to a user's willingness to adopt and use technology for the tasks it is designed to support (Teo, 2010a). Previously, procurers of technology could rely on organisational authority to ensure that technology was used, as is the case in many business settings. In education, this is usually not the case because users have greater volition in deciding which technology to use and when to use it. For example, students can often decide whether to study through e-learning or not without any academic consequences. Under these conditions, the success of any technological initiatives such as e-learning may be substantially affected by the degree to which potential users (students) are willing to use it. 


\section{Related e-learning studies}

Duggan, Hess, Morgan, Kim \& Wilson (1999) found that research on e-learning generally had focused on technical aspects of e-learning, while studies on the reactions and acceptance of users towards e-learning were limited. Recent studies have rendered mixed views about the instructors' and learners' responses to and experiences with elearning (Abdelaziz, Kamel, Karam \& Abdelrahman, 2011; Bhatiasevi, 2011; Lim, Hong \& Tan, 2011; Paechter \& Maier, 2010; Saekow \& Samson, 2011; Siritongthaworn et al., 2006; Suanpang \& Petocz, 2006). These authors suggested that more research should be conducted to examine the determinants that impact on e-learning

Within the Thai context, Suanpang and Petocz (2006) conducted a study to investigate the efficiency and effectiveness of an online learning system at a university. Their study reported that students in the online learning environment performed better than those who were enrolled in the traditional class. These students also possessed a higher level of satisfaction with their learning compared to their counterparts in the traditional classes. Mirroring similar outcomes, a study by Bhatiasevi (2011) found that Thai students expressed willingness to use the e-learning system and overcome usability problems in order to achieve better grades. These students also showed greater satisfaction towards the e-learning materials. However, a study conducted in four other Thai universities revealed that instructors and students faced great challenges when using e-learning. Siritongthaworn, Krairit, Dimmitt and Paul (2006) reported that all instructors interviewed had little or no experience with online teaching methodology. Consequently, they lacked confidence in implementation of elearning. From the students' perspective, they revealed that poor availability of access points, slow network communications, and a lack of software application as their challenges to participating in e-learning. These findings were supported by Saekow and Samson (2011), who found that Thai instructors had failed to see the value of and were disinterested in implementing e-learning, while students had complained about the poor ICT infrastructure.

\section{Aim of this study}

The aim of this study is to explore the e-learning acceptance of students drawn from three public universities in Thailand. The research questions that guide this study are:

1. What is the general level of e-learning acceptance among the students?

2. To what extent is e-learning acceptance associated with age, computer experience, and perceived competence?

3. Are there significant differences in e-learning acceptance by gender, age, perceived computer competence, and perceived technology competence?

\section{Methodology}

\section{Participants and procedures}

Participants were 377 students from three publicly-funded universities in Thailand. Two universities were situated at the middle of Thailand and one at the North of Thailand. All three have faculties that are traditionally found in universities. These are Medicine, Engineering, Arts and Social Sciences, Science, and Fine Arts, to name a few. The students in this study were enrolled in the Bachelor of Education program at their 
respective universities. Among them, 68.2\% (257) were females and the mean age of all participants was 20.30 years $(\mathrm{SD}=1.07)$. The mean years of computer usage within this sample was $10.41(\mathrm{SD}=2.91)$.

Participants responded to an invitation issued by their lecturers during the study term. All participants were volunteers and they were briefed on the purpose of this study and informed of their rights to not participate or withdraw from completing the questionnaire at anytime during the data collection. No reward was given in monies or kind. Participants took about 20 minutes to complete the paper-based questionnaire.

\section{Instrumentation}

The research instrument used in this study was the e-learning acceptance measure (ElAM). The ElAM was developed by Teo (2010b) in response to the need for a Likerttype instrument to measure the degree to which potential users are willing to use elearning. This instrument presented an alternative to existing measures of e-learning and online learning that have emphases are upon students' perception of web quality, self-efficacy, or attitude towards the Internet. The ElAM is a 21 -item instrument that measures three hypothesised constructs of e-learning: tutor quality, perceived usefulness, and facilitating conditions. Comprising eight, nine, and four items respectively, these constructs have good composite reliability: tutor quality $(\alpha=.987)$, perceived usefulness $(\alpha=.976)$, and facilitating conditions $(\alpha=.996)$. The ElAM was developed and validated through two studies with a total sample of 386 university students in the original study and found to be a psychometrically-sound measure of e-learning acceptance for university students. A 7-point Likert-type scale was used in the ElAM with $1=$ strongly disagree to $7=$ strongly agree. The ElAM is shown in the Appendix.

In the e-learning environment, the role of tutors shifts from that of transmitting knowledge to the new role as a facilitator, coach, and mentor. The course tutor may act as a trouble shooter or be relied upon to resolve hardware and software issues. Teo (2010b) found that when learners regarded their tutors to be of high quality, they would be more willing to use e-learning and feel supported in their learning. On perceived usefulness, it was found to have a positive effect on students' intention to use a particular system (e.g., e-learning). That is, students are more likely to use elearning when they perceive e-learning to be useful for them to learn in a more effective way and attain a higher performance in their studies.

Facilitating conditions are those in the environment that influence a person's desire to perform a task (e.g., participate in e-learning). For example, Groves and Zemel (2000) found that technical support (e.g., skills training, information or materials available and administrative support) was rated as a very important factor which influenced the use of instructional technologies in teaching. Applied to e-learning, evidence for the importance of support structures for end-users in e-learning courses is found in studies by Miller and $\mathrm{Lu}(2003)$.

From the original English version, the ElAM was translated into the Thai language for the participants in this study by a professor and her colleagues who were experienced in the use of the English and Thai languages. They held doctorates in educational technology and were familiar with the translation standard required in academic research. 


\section{Results}

\section{Descriptive statistics}

Table 1 shows the means, standard deviations, skewness, and kurtosis indices. The mean values of all items were above the mid-point of 4.00 and ranged from 5.00 (FC2) to 5.79 (TQ2). The standard deviations ranged from 0.84 to 1.33 , reflecting a narrow spread of scores from the mean. The skewness and kurtosis indices ranged from - 1.07 to 0.34 and - 0.89 to 1.11 respectively. Following Kline's (2005) recommendations, the data in this study were considered to be univariate normal. According to Teo (2010b), the total score for ElAM ranges from 21 to 147, with scores leaning towards 147 indicating higher level of e-learning acceptance. The mean score for this study sample is 111.36, suggesting a high level of e-learning acceptance.

Table 1: Descriptive statistics of the 21-item ElAM

\begin{tabular}{|l|c|c|c|c|c|}
\hline \multirow{2}{*}{ Tutor's } & Item & Mean & Std dev & Skewness & Kurtosis \\
\cline { 2 - 6 } quality & TQ1 & 5.43 & 0.84 & -0.11 & 0.03 \\
\cline { 2 - 6 } & TQ2 & 5.79 & 0.91 & -1.07 & 3.13 \\
\cline { 2 - 6 } & TQ3 & 5.23 & 1.19 & -0.64 & -0.54 \\
\hline & TQ4 & 5.40 & 0.91 & -0.06 & 0.01 \\
& TQ5 & 5.45 & 1.02 & -0.66 & 0.92 \\
\cline { 2 - 6 } & TQ6 & 5.31 & 1.13 & -0.18 & -0.28 \\
\cline { 2 - 6 } uerceived & TQ7 & 5.32 & 1.11 & -0.17 & -0.29 \\
\cline { 2 - 6 } & TQ8 & 5.43 & 1.05 & -0.69 & 1.06 \\
\cline { 2 - 6 } & PU1 & 5.17 & 1.24 & -0.07 & -0.89 \\
\cline { 2 - 6 } & PU2 & 5.03 & 1.33 & 0.07 & -1.18 \\
\cline { 2 - 6 } & PU3 & 5.54 & 0.96 & -0.22 & -0.37 \\
\cline { 2 - 6 } & PU4 & 5.29 & 1.08 & -0.61 & 0.07 \\
\cline { 2 - 6 } & PU5 & 5.44 & 1.10 & -0.89 & 1.11 \\
\cline { 2 - 6 } & PU6 & 5.36 & 1.09 & -0.65 & 0.04 \\
\cline { 2 - 6 } & PU7 & 5.49 & 0.96 & -0.29 & -0.35 \\
\cline { 2 - 6 } & PU8 & 5.08 & 0.91 & -0.06 & 0.23 \\
\hline \multirow{4}{*}{$\begin{array}{l}\text { Facilitating } \\
\text { conditions }\end{array}$} & PU9 & 5.15 & 0.91 & 0.12 & -0.89 \\
\cline { 2 - 6 } & FC1 & 5.17 & 0.94 & 0.07 & -0.87 \\
\hline \multirow{4}{*}{ FC2 } & 5.00 & 0.96 & 0.34 & -0.82 \\
& FC3 & 5.10 & 1.07 & -0.16 & -0.66 \\
& FC4 & 5.20 & 0.96 & -0.07 & -0.67 \\
\hline
\end{tabular}

\section{Correlational analyses}

Table 2 shows the correlational relationship between the ElAM and age, computer experience, and perceived competence. Age and computer experience (denoted as the number of years a user has used the computer) were negatively correlated with all the factors in ElAM. In the case of computer experience, they were not significantly related the ElAM factors. All factors in ElAM correlated significantly and positively with perceived competence at the $p<.01$ level. While the associations between the factors of 
ElAM and age were fairly consistent, ranging from -.239 to -.279 , those of perceived competence were wider in range. Of the relationship between perceived competence and the ElAM factors, tutor quality has the stronger association $(r=.673, p<.01)$ while facilitating conditions has the weakest $(r=.278, p<.01)$.

Table 2: Correlation among factors in ElAM and age, computer experience, and perceived competence

\begin{tabular}{|l|c|c|c|}
\hline \multicolumn{1}{|c|}{ Factor } & Age & $\begin{array}{c}\text { Computer } \\
\text { experience }\end{array}$ & $\begin{array}{c}\text { Perceived } \\
\text { competence }\end{array}$ \\
\hline Tutor quality & $-.239^{* *}$ & -.055 & $.673^{\star *}$ \\
\hline Perceived usefulness & $-.244^{* *}$ & -.078 & $.631^{\star *}$ \\
\hline Facilitating conditions & $-.279^{* *}$ & -.089 & $.278^{\star *}$ \\
\hline Total measure & $-.263^{\star *}$ & -.075 & $.611^{* *}$ \\
\hline Note: ${ }^{* *} p<.01$ &
\end{tabular}

\section{MIMIC modelling}

The multiple indicators, multiple causes (MIMIC) model is a method to explain the event under investigation when it is believed that the observed variables are manifestations of an underlying, unobserved latent that is affected by other exogenous variables that "cause" and influence the latent factor(s). MIMIC was first proposed by Joreskog and Goldberger (1975) as a procedure to estimate a model where MIMIC of a latent variable is observed. In MIMIC modelling, two parts are computed: the measurement part that displays the causal link among the latent variables and the observed causes, and the structural part which shows how the latent variables are estimated through the observed variables (the indicators). A MIMIC model also allows for a dichotomous group comparison (e.g. gender) using cause indicators as exogenous variables. This is often used as an alternative to multiple-group comparisons where bigger sample sizes are required (Brown, 2006). The modelling process follows established procedures for a MIMIC model recommended by Kline (2005). The MIMIC model has an opposite layout from a path model in that the dichotomous variable (or dependent variable) is represented at the left side instead of the right side of the model. Figure 1 shows the MIMIC model in this study.

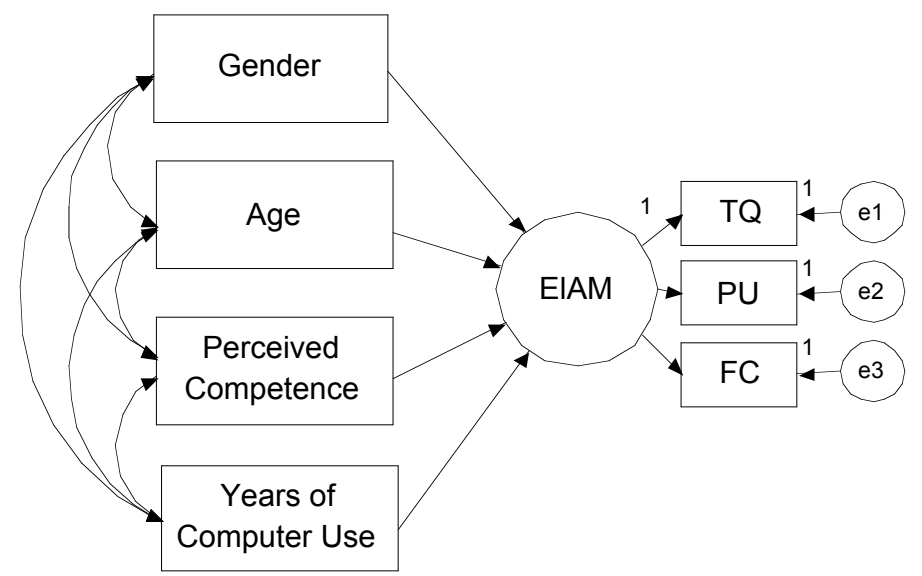

Figure 1: MIMIC model of e-learning acceptance and its covariates 
In this study, MIMIC modelling was used to assess whether significant differences are present in e-learning acceptance by the users' domain (gender, age, perceived competence, and years of computer use). MIMIC modelling is a technique within structural equation modelling (SEM) that contains two advantages over the use of traditional statistics (e.g., $t$-tests). First SEM allows simultaneous analysis of a model with latent variables and observed indicators and second, measurement error are modelled and computed in SEM to facilitate more precise estimation of item reliability. The exogenous variables in this study that are assumed to explain the latent factor, elearning acceptance (TQ, PU, and FC), are gender, age, computer experience, and years of computer use (perceived competence). This part of the model can be viewed as three multiple regressions: $\mathrm{TQ}, \mathrm{PU}$, and $\mathrm{FC}$ on gender, age, computer experience, and perceived competence. For example, if gender is coded such that males are 0 and females 1, a negative coefficient for the regression of TQ on gender would indicate that females have a lower level of perception of tutor quality than males. Hence, there are multiple indicators, which reflect the underlying factors, and multiple causes, which affect the underlying factors. For purposes of dichotomising the age, computer experience, and perceived competence variables, the median aggregate score for each variable was used and converted into $0=$ young and $1=$ old for age, $0=$ less experience and $1=$ more experience for computer experience, and $0=$ low competence and $1=$ high competence for perceived competence. Figure 1 shows the MIMIC model which incorporates these variables and the effects of gender on the latent variables that are represented by arrows from these variables to the latent factors.

The fit of the model was estimated using the maximum likelihood (MLE) procedure and assessed using a number of fit indices the representing absolute, comparative, and parsimonious aspects of model fit (Hair, Black, Babin \& Anderson, 2010). They were: $\chi^{2}, \chi^{2} / d f$, Tucker-Lewis index (TLI), Comparative Fit Index (CFI), Root Mean Squared Error of Approximation (RMSEA), and Standardised Root Mean Residual (SRMR). A $\chi^{2} /$ df ratio of less than 3.0 indicated good overall model fit. To achieve acceptable model fit, the TLI and CFI should be greater than .95, and the RMSEA and SRMR should be equal or smaller than .08 (Hu \& Bentler, 1999).

The fit of this model was good $\left(\chi^{2}=13.82, \mathrm{df}=6, p=.032, \chi^{2} / \mathrm{df}=2.304, \mathrm{TLI}=.983\right.$, CFI $=.995, \mathrm{RMSEA}=.059, \mathrm{SRMR}=.041)$. The parameter estimates revealed that all three indicators (TQ, PU, and FC) were significant in explaining e-learning acceptance (TQ: $\beta=.839$; PU: $\beta=1.000$; FC: $\beta=.714$ ). The proportion of explained variance of the three indicator variables was .820 for TQ, 1.000 for PU, and .510 for FC. Together, these three variables explained $26.5 \%$ of the variance in students' e-learning acceptance. The regression part (left side) of the model showed that there were significant differences in e-learning acceptance by age $(\beta=-.116 ; p>.001)$ and perceived competence $(\beta=.521$; $p>$.001). The other two user domain variables did not have significant influences on elearning acceptance (gender: $p=.147$ and years of computer use, $p=.125$ ). The results also revealed that younger students and students who had used computers more had a higher level of e-learning acceptance than the older students and those students who had spent less time with computers.

\section{Discussion and implications for Asian contexts}

This study explored the e-learning acceptance of a sample of students drawn from three public universities in Thailand. The results revealed that participants had an above-average level of e-learning acceptance. Within a proposed range of 21 to 147 by Teo (2010b), the mean score for the participants in this study was 111.36, approaching 
the maximum score of 147 in the ElAM. Such a high level of acceptance may be attributed to the emphasis on e-learning in Thailand at the university (e.g., King Mongkut's SIT) and national level (e.g., Thailand Cyber University project). It is possible that with visible official sanctions and endorsements for e-learning at the higher education sector comes greater awareness among the students in the universities, thus leading to a higher level of acceptance of e-learning. The mean score of 111.36 in this study compares well with the combined Singapore samples $(\mathrm{N}=387)$ in Teo (2010b) with a mean score of 130.05 , which is also inclined towards the upper limit of 147. The differences may be due to the measurement error inherent in the translation process of the ElAM that was performed for this study. To test the validity of this conjecture, a measurement invariance study should be conducted in future research.

This study also found that e-learning acceptance was significantly and positively correlated with perceived competence, but negatively correlated with age. This suggests that when users perceive themselves to be competent in the use of technology, they are likely to accept and participate in e-learning. This was consistent with Teo (2009) who found that users' favourable perceptions of their ability to use technology have a significant and positive influence on their behavioural intention to use technology. In addition, the perception of one's ability to use technology also positively and significantly influences behavioural intention to use technology, indirectly through perceived usefulness and perceived ease of use. The negative yet significant relationships between age and e-learning acceptance suggest that younger students tend to accept e-learning more than the older ones. This has implications on the continuing education and lifelong learning policies in Thailand because it is crucial for the service providers (e.g., universities, lifelong learning centres) to reach out effectively to potential students of all ages, not just the younger ones. Within higher education institutions, administrators and academic staff should implement and adjust their strategies to enable learners of all ages to embrace e-learning with comparable enthusiasm. If the long-term goals of e-learning in developing countries include providing an alternative channel for teaching and learning, with a view to promoting equity in education among people of different socio-economic classes, then much has to be done to reach out to potential users of all ages. More than just the variety of courses for everybody, designers of e-learning systems should consider the cognitive, environmental, and technological factors that impact on users' acceptance and adoption for successful implementation.

Lastly, this study found significant differences in e-learning by age and perceived competence. In other words, younger and older users, and users who perceive themselves to be highly or lowly competent in technology use accept e-learning differently in significant ways, echoing the results of the correlational analyses in this study. However, no significant gender difference in e-learning was found in this study. This is noteworthy and contrary to recent studies that have found gender differences in technology acceptance. For example, Liaw (2002) found that female teachers expressed less interest in technology and placed lower importance on technology in the teaching and learning process compared to male teachers. On the other hand, male teachers demonstrated greater interest in technology and exhibited a higher level of confidence in their ability to use technology. This may have led to a possibility that females may not enter careers that are related to technology although equal opportunities are available for females in such industries (Anderson, Lankhear, Timms \& Courtney, 2008). With empirical support for a lack of gender difference in e-learning acceptance, efforts could be channelled to addressing other issues, such as age and perceived competence of potential and existing students. 


\section{Limitations}

Despite the care given to ensuring that the methodology is sound, this study has limitations. Firstly, as data were collected through self-reports, this may have led to the common method variance, a situation that may inflate the true associations between variables. Secondly, the sample was taken only from three universities in Thailand and this may not represent the students in all universities in Thailand. Thirdly, the variance of the dependent variable, e-learning was explained by its three factors by a mere $26.5 \%$, leaving $73.5 \%$ unexplained. It is possible that, in the pursuit of parsimony, Teo (2010b) may have excluded other variables in the ElAM that may impact significantly on e-learning. This raises the need to consider additional variables for inclusion in the ElAM to achieve greater validity and efficiency. Some examples of variables that could be considered for inclusion in the ElAM could be adapted from the model and theories that have been found to explain users' acceptance of a type of technology (e.g., elearning, learning management system).

From the literature, the Technology Acceptance Model (TAM) (Davis, 1989), Theory of Planned Behaviour (TPB) (Ajzen, 1991), and the Unified Theory of Acceptance and Use of Technology (UTAUT) (Venkatesh, Morris, Davis, \& Davis, 2003) have been used by many researchers as the framework to explain technology acceptance among users in educational contexts. The aforementioned models are similar to the one used in the present study as they are aimed at exploring user acceptance and behaviour of an information system (e.g., e-learning). However, unlike the present model, the TAM, TPB and UAUT can also be used to predict user's technology acceptance, although recent studies have suggested that some variables in these models such as perceived ease of use, subjective norm, computer self-efficacy, and users' beliefs about technology are significant predictors of attitudes towards computer use and intention to use computers. Hence it is reasonable to expect these variables to have significant influences on e-learning as well (Wong \& Teo, 2009; Paraskeva, Bouta \& Papagianni, 2008; Saade \& Kira, 2007; Teo, 2009; Teo \& Lee, 2010; Teo \& van Schaik, 2009; Teo, Wong \& Sing, 2008; Teo, Lee, Chai \& Wong, 2009). Over time, as e-learning becomes more prevalent, inequalities in access to technologies or users' abilities may result hence affecting e-learning acceptance (Crawford \& McKenzie, 2011). Future research on the sociological factors of e-learning may be needed to unpack and address the issues that will continue to confront users of e-learning.

\section{Conclusions}

From the results, younger students and students who had more confidence in using computers showed a higher level of e-learning acceptance than the older students and those students who reported a lower level of perceived competence in using computers. One strategy is to identify and target older students' use of computers with a view to raising their perceived competence. This could be achieved through providing structured training on computer skills (Teo \& Koh, 2010), widening access to the use of computing hardware and software, and granting incentives to use computers for personal and educational purposes. Another strategy is through curricular innovations whereby the use of computers is embedded in teaching and learning. Using a holistic approach, educators model the use of computers for instructional purposes and students are being encouraged to use computers to fulfil course requirements. Computers may also be used to design and administer assessment tasks within and outside the school premises. In the case of school leaders, 
they cultivate a conducive environment for computer usage by building infrastructure and ensuring that adequate technical support is in place.

Thailand is one of the developing countries in Asia and it is fair to say that the educational issues and challenges that the country faces are shared by other developing countries in the region. E-learning is among the most prolific pedagogies in modern educational practice, with great potential to impact on teaching and learning that is constrained by physical location and diverse social needs, among other things. Over the years, much has been done in areas of strategic planning and equipping for elearning. Given such high stakes, educators and policy-makers should take a step back to consider whether users' acceptance of e-learning has kept abreast with content creation, infrastructure development, and other forms of capacity building. It is hoped that this study will offer some insights on the contributions that acceptance research can potentially make to advance the goals of e-learning in Asia.

\section{Acknowledgment}

The authors would like to express their thanks to the colleagues at Chulalongkorn, Naresuan and Silpakorn Universities for assisting with data collection.

\section{References}

Abdelaziz, M. Kamel, S. S., Karam, O. \& Abdelrahman, A. (2011). Evaluation of E-learning program versus traditional lecture instruction for undergraduate nursing students in a faculty of nursing. Teaching and Learning in Nursing, 6(2), 50-58. http: / / www.jtln.org/ article/S1557-3087(10)00091-0/ abstract

Afshari, M., Bakar, K. A., Wong, S. L., Samah, B. A. \& Fooi, F. S. (2008). School leadership and information communication technology. Turkish Online Journal of Educational Technology, 7(4), 82-91. http: / / www.tojet.net/articles/749.pdf

Ajzen, I. (1991). The theory of planned behavior. Organizational Behaviour and Human Decision Processes, 50, 179-211. http: / / people.umass.edu/psyc661/pdf/tpb.obhdp.pdf

Anderson, N., Lankhear, C., Timms, C. \& Courtney, L. (2008). 'Because it's boring, irrelevant and I don't like computers': Why high school girls avoid professionally-oriented ICT subjects. Computers E Education, 50(4), 1304-1318. http:/ / dx.doi.org/10.1016/j.compedu.2006.12.003

Bhatiasevi, V. (2011). Acceptance of e-learning for users in higher education: An extension of the technology acceptance model. The Social Sciences, 6(6), 513-520. http: / / dx.doi.org/10.3923/ sscience.2011.513.520

Brown, T. A. (2006). Confirmatory factor analysis for applied research. NY: Guilford Press.

Cheung, W. \& Huang, W. (2005). Proposing a framework to assess Internet usage in university education: An empirical investigation from a student's perspective. British Journal of Educational Technology, 36(2), 237-254. http: / / dx.doi.org/10.1111/j.1467-8535.2005.00455.x

Crawford, N. \& McKenzie, L. (2011). E-learning in context: An assessment of student inequalities in a university outreach program. Australasian Journal of Educational Technology, 27(3), 531545. http:/ / www.ascilite.org.au/ajet/ajet27/ crawford.html

Davis, F. D. (1989). Perceived usefulness, perceived ease of use, and user acceptance of information technology. MIS Quarterly, 13(3), 319-340. http:/ / www.jstor.org/stable/249008

Dawson, S. (2006). Online forum discussion interactions as an indicator of student community. Australasian Journal of Educational Technology, 22(4), 495-510.

http:/ / www.ascilite.org.au/ajet/ajet22/dawson.html 
Duggan, A., Hess, B., Morgan, D., Kim, S. \& Wilson, K. (1999). Measuring students' attitude toward educational use of the Internet. (ERIC Reproduction Service No. ED 429 117). http: / / www.eric.ed.gov/PDFS /ED429117.pdf

Groves, M. M. \& Zemel, P. C. (2000). Instructional technology adoption in higher education: An action research case study. International Journal of Instructional Media, 27(1), 57-65. http:/ / www.highbeam.com/doc/1G1-60476994.html

Hair, J. F., Black, B., Babin, B. \& Anderson, R.E. (2010). Multivariate data analysis: A global perspective (6th ed.). Upper Saddle River, NJ: Prentice-Hall International.

Hu, L. \& Bentler, P. M. (1999). Cutoff criteria for fit indexes in covariance structure analysis: Conventional criteria versus new alternatives. Structural Equation Modeling, 6(1), 1-55. http: / / dx.doi.org/10.1080/10705519909540118

Johnson, E. M., Cowie, B., De Lange, W., Falloon, G., Hight, C. \& Khoo, E. (2011). Adoption of innovative e-learning support for teaching: A multiple case study at the University of Waikato. Australasian Journal of Educational Technology, 27(3), 499-513. http: / / www.ascilite.org.au/ajet/ajet27/johnson.html

Joreskog, K. \& Goldberger, S. (1975). Estimation of a model with multiple indicators and multiple causes of a single latent variable. Journal of American Statistical Association, 70, 631639. http:/ / www.jstor.org/stable/ 2285946

Kline, R. B. (2005). Principles and practice of structural equation modeling (2nd Ed.). New York: Guilford Press.

Liaw, S. S. (2002). Understanding user perceptions of world-wide web environments. Journal of Computer Assisted Learning, 18(2), 137-148. http:/ / dx.doi.org/10.1046/j.0266-4909.2001.00221.x

Lim, B., Hong, K. S. \& Tan, K. W. (2008). Acceptance of e-learning among distance learners: A Malaysian perspective. In Hello! Where are you in the landscape of educational technology? Proceedings ascilite Melbourne 2008. http:/ / www.ascilite.org.au/conferences/ melbourne08/procs/lim.pdf

Miller, M. T. \& Lu, M. Y. (2003). Serving non-traditional students in e-learning environments: Building successful communities in the virtual campus. Educational Media International, 40(12), 163-169. http:/ / dx.doi.org/10.1080/0952398032000092206

Moses, P., Khambari, M. N. \& Wong, S. L. (2008). Laptop use and its antecedents among educators: A review of the literature. European Journal of Social Sciences, 7(1), 104-114. http: / / www.eurojournals.com/ejss_7_1_09.pdf

Paechter, M. \& Maier, B. (2010). Online or face-to-face? Students' experiences and preferences in e-learning. The Internet and Higher Education, 13(4), 292-297. http: / / dx.doi.org/10.1016/j.iheduc.2010.09.004

Paraskeva, F., Bouta, H. \& Papagianni, A. (2008). Individual characteristics and computer selfefficacy in secondary education teachers to integrate technology in educational practice. Computers \& Education, 50(3), 1084-1091. http:/ / dx.doi.org/10.1016/j.compedu.2006.10.006

Saade, R. G. \& Kira, D. (2007). Mediating the impact of technology usage on perceived ease of use by anxiety. Computers $\mathcal{E}$ Education, 49(4), 1189-1204. http: / / dx.doi.org/10.1016/j.compedu.2006.01.009

Saekow, A. \& Samson, D. (2011). E-learning readiness of Thailand's universities comparing to the USA's cases. International Journal of e-Education, e-Business, e-Management and e-Learning, 1(2), 126-131. http: / / www.ijeeee.org/Papers/020-Z0001.pdf

Siritongthaworn, S., Krairit, D., Dimmitt, N. J. \& Paul, H. (2006). The study of e-learning technology implementation: A preliminary investigation of universities in Thailand. Education and Information Technologies, 11(2), 137-160. http: / / dx.doi.org/10.1007/s11134-0067363-8 
Southeast Asian Ministers of Education Organization (2010). Report of the Status of ICT integration in Education in South East Asian countries. [viewed 15 Nov 2011] http: / / www.icde.org/ filestore/Resources/Reports/SEAMEO_ICT-Integration-Education2010.pdf

Suangpang, P. \& Petocz, P. (2006). E-learning in Thailand: An analysis and case study. International Journal on E-Learning, 5(3), 415-438. http:/ / editlib.org/p/5708

Teo, T. (2009). Modelling technology acceptance in education: A study of pre-service teachers. Computers \& Education, 52(2), 302-312. http:/ / dx.doi.org/10.1016/j.compedu.2008.08.006

Teo, T. (2010a). The development, validation, and analysis of measurement invariance of the Technology Acceptance Measure for Preservice Teachers (TAMPST). Educational and Psychological Measurement, 70(6), 990-1006. http: / / dx.doi.org/ 10.1177/ 0013164410378087

Teo, T. (2010b). Development and validation of the E-learning Acceptance Measure (ElAM). The Internet and Higher Education, 13, 148-152. http: / / dx.doi.org/10.1016/j.iheduc.2010.02.001

Teo, T. \& Koh, J. H. L. (2010). Assessing the dimensionality of computer self-efficacy among preservice teachers in Singapore: A structural equation modeling approach. International Journal of Education and Development using Information and Communication Technology, 6(3), 7-18. http: / / ijedict.dec.uwi.edu /include/ getdoc.php?id=4230\&article=1061\&mode=pdf

Teo, T. \& Lee, C. B. (2010). Explaining the intention to use technology among student teachers: An application of the theory of planned behaviour (TPB). Campus-Wide Information Systems, 27(2), 60-67. http:/ / dx.doi.org/10.1108/10650741011033035

Teo, T. \& van Schaik, P. (2009). Understanding technology acceptance in pre-service teachers: a structural-equation modeling approach. The Asia-Pacific Education Researcher, 18(1), 47-66. http: / / www.philjol.info/philjol/index.php/TAPER/article/view/1035/941

Teo, T., Wong, S. L. \& Chai, C. S. (2008). A cross-cultural examination of the intention to use technology between Singaporean and Malaysian pre-service teachers: An application of the technology acceptance model (TAM). Educational Technology \& Society, 11(4), 265-280. http: / / www.ifets.info/journals/11_4/19.pdf

Teo, T., Lee, C. B., Chai, C. S. \& Wong, S. L. (2009). Assessing the intention to use technology among pre-service teachers in Singapore and Malaysia: A multigroup invariance analysis of the technology acceptance model (TAM). Computers \& Education, 53(3), 1000-1009. http: / / dx.doi.org/10.1016/j.compedu.2009.05.017

Venkatesh, V., Morris, M. G., Davis, G. B. \& Davis, F. D. (2003). User acceptance of information technology: Toward a unified view. MIS Quarterly, 27(3), 425-478. http:/ / www.jstor.org/ stable/30036540

Wong, S. L., Atan, H. \& Sabudin, S. (2010). Exploring teachers' perceptions of their pedagogical role with computers: A case study in Malaysia. Procedia - Social and Behavioral Sciences, 2(2), 388-391. http: / / dx.doi.org/10.1016/j.sbspro.2010.03.031

Wong, S. L., Ng, S. F., Nawawi, M. \& Tang, S. H. (2005). Experienced and inexperienced Internet users among pre-service teachers: Their use and attitudes toward the Internet. Educational Technology and Society, 8(1), 90-103. http:// www.ifets.info/journals/8_1/12.pdf

Wong, S. L. \& Teo, T. (2009). Investigating the technology acceptance among student teachers in Malaysia: An application of the technology acceptance model (TAM). Asia-Pacific Education Researcher, 18(2), 261-272.

Yee, H. T., Wong, S. L., Mohamad Ayub, A. F. \& Mahmud, R. (2009). A review of the literature: Determinants of online learning among students. European Journal of Social Sciences, 8(2), 246252. http:// www.eurojournals.com/ejss_8_2_05.pdf 


\section{Appendix: Items in the E-learning Acceptance Measure (EIAM)}

\begin{tabular}{|c|c|c|}
\hline & & Item \\
\hline During & TQ1 & My tutor could explain the concepts clearly \\
\hline e-learning & TQ2 & My tutor was knowledgeable in ICT \\
\hline & TQ3 & I was satisfied with the answers given by my tutor \\
\hline & TQ4 & My tutor was focused on helping me to learn \\
\hline & TQ5 & The tutorial activities were well-managed \\
\hline & TQ6 & My tutor was accessible when I needed to consult them \\
\hline & TQ7 & My tutor was patient when they interacted with me \\
\hline & TQ8 & The group sessions were well facilitated \\
\hline As a result of & PU1 & I am able to apply the course contents in my work \\
\hline e-learning & PU2 & What I had learned from the course is useful to my work \\
\hline & PU3 & I am able to use the knowledge from the course to help my colleagues \\
\hline & PU4 & I can contribute to my work place more \\
\hline & PU5 & I can integrate ICT in my work creatively \\
\hline & PU6 & $\begin{array}{l}\text { I know how to search, evaluate and select appropriate IT resources to } \\
\text { support my work }\end{array}$ \\
\hline & PU7 & I am able to adopt and adapt ICT resources in my work \\
\hline & PU8 & I can integrate ICT in my work with minimal help \\
\hline & PU9 & I can manage ICT resources more effectively at my work place \\
\hline & FC1 & Guidance was available to me \\
\hline help to use the & FC2 & Specialised instruction was available to help me \\
\hline system & FC3 & A specific person was available to provide assistance \\
\hline & FC4 & I knew where to find it \\
\hline
\end{tabular}

TQ = Tutor's quality; PU = Perceived usefulness; FC = Facilitating conditions

\section{Authors: Dr Timothy Teo, Associate Professor}

University of Auckland, New Zealand

Email: t.teo@auckland.ac.nz Web:

http: / / www.education.auckland.ac.nz/uoa/ timothy-teo

Dr Wong Su Luan, Associate Professor, Universiti Putra Malaysia

Email:wsuluan@gmail.com Web: http:/ / profile.upm.edu.my/suluan

Dr Thapanee Thammetar, Assistant Professor, Silpakorn University, Thailand

Email: kobthapanee@gmail.com Web: http:/ / www.su.ac.th/

Dr Wisa Chattiwat, Associate Professor, Silpakorn University, Thailand

Email: wisa@su.ac.th Web: http:/ / www.su.ac.th/

Please cite as: Teo, T., Wong, S. L., Thammetar, T. \& Chattiwat, W. (2011). Assessing elearning acceptance by university students in Thailand. In Hong, K. S. \& Lai, K. W.

(Eds), ICT for accessible, effective and efficient higher education: Experiences of

Southeast Asia. Australasian Journal of Educational Technology, 27(Special issue, 8), 1356-

1368. http: / / www.ascilite.org.au/ajet/ajet27/teo.html 